\title{
STRATIGRAPHIC POSITION OF FLUVIAL AND AEOLIAN DEPOSITS IN THE ŻABINKO SITE (W POLAND) BASED ON TL DATING
}

\author{
PAWEŁ ZIELIŃSKI ${ }^{1}$, ROBERT J. SOKOLOWSKI ${ }^{2}$, STANISŁAW FEDOROWICZ ${ }^{3}$ \\ and MICHAŁ JANKOWSKI ${ }^{4}$ \\ ${ }^{I}$ Department of Physical Geography and Paleogeography, Maria Curie-Skłodowska University, \\ Kraśnicka 2cd, 20-718 Lublin, Poland \\ ${ }^{2}$ Department of Marine Geology, University of Gdańsk, \\ Pitsudskiego 46, 80-950 Gdańsk, Poland \\ ${ }^{3}$ Department of Geomorphology and Quaternary Geology, University of Gdańsk, \\ Bażyńskiego 4, 80-950 Gdańsk, Poland \\ ${ }^{4}$ Department of Soil Science, Nicolaus Copernicus University, \\ Gagarina 9a, 87-100 Toruń, Poland
}

Received 28 May 2010

Accepted 31 August 2010

\begin{abstract}
The known from literature Żabinko site is situated in the Warta Pradolina, within the dune field occurring on the bifurcation terrace. In the site we found fluvial, fluvio-aeolian and aeolian deposits, paleosols, and organic infillings of the inactive river channels. The purpose of the study was to determine stratigraphic position of the deposit units distinguished on the basis of lithofacial analysis, pedological description and thermoluminescence dating. The obtained results well correspond to the previously published ones, and new units were also found.
\end{abstract}

Keywords: fluvial and aeolian deposition, TL dating, Plenivistulian, Late Vistulian, Holocene, Warta river valley.

\section{INTRODUCTION}

Rapid climate changes occurred at the turn of the Vistulian and Holocene - from climatic pessimum connected with the maximum extent of the Vistulian ice sheet in the Plenivistulian to climate warming in the Early Holocene (Nowaczyk, 1986; van Huissteden and Kasse, 2001; Kasse, 2002; Bogaart et al., 2003; Kasse et al., 2007; Rasmussen et al., 2008). Evolution of deposition environments was closely connected with those climate changes. It is especially visible in the profiles situated on floodplains of the river valleys in extraglacial zone during the last glaciation. The sedimentary succession, com-

Corresponding author: P. Zieliński e-mail: pziel@umcs.pl monly described in scientific literature, is the record, from bottom to top, of deposition processes connected with braided river, alternating fluvial and aeolian accumulation, and aeolian deposition resulting in the formation of dunes (Bohncke et al., 1995; Manikowska, 1995; Kasse, 2002; Zieliński, 2007). In the European sandy belt (Kasse, 1997, Zeeberg, 1998) there are found more and more sites permitting to reconstruct the variability of nature, dynamics and age of deposition processes. The determination of stratigraphic position of examined processes is mostly based on radiocarbon dating and/or palynological analyses of organogenic layers (Kozarski and Nowaczyk, 1991; Bohncke et al., 1995; Kaiser et al., 2006). However, luminescence dating (TL and OSL) is more and more often used due to rare occurrence of or- 
ganic material in examined deposits (Kasse et al., 2003, 2007; Koster, 2005; Rittenour, 2008).

\section{REGIONAL SETTING AND PREVIOUS INVES- TIGATIONS}

In Poland one of key sites with fluvial-aeolian succession is Żabinko. It is situated in a complex dune in the Warta Pradolina, about $20 \mathrm{~km}$ to the south of Poznan. The complex dune includes a parabolic dune and two superimposed dune forms adjoining its proximal part (Fig. 1). The parabolic dune reaches the height of 15-17 $\mathrm{m}$ in the front part and the length of over $2.5 \mathrm{~km}$ along the ridge. Its arm-span is about $1 \mathrm{~km}$ and the southern arm is about $900 \mathrm{~m}$ longer from the northern one. The superimposed dune forms reach the height of up to $20 \mathrm{~m}$, and the length of up to $600 \mathrm{~m}$ along the ridge. Their arms are short (150-250 m), and the arm-span is about $300 \mathrm{~m}$. Many deflation hollows and troughs occur in the proximal part of the complex dune, especially in the northern part of the site. The bifurcation terrace composed of the Vistulian sands with depressions filled with peat occurs in the dune foreland, i.e. on the east side. Aeolian cover sands occur in the inner zone of the complex dune (Nowaczyk. 1986; Kozarski and Nowaczyk. 1995, Bohncke et al.. 1995). The described deposits are underlain by glacigenic deposits from the Saalian Glaciation and fluvioglacial deposits from the Poznań recession phase of the Weichselian Glaciation.

The first investigations in the Żabinko site were carried out by Nowaczyk (1986), Tobolski (1988), Antczak (1986) and Kozarski et al. (1988). They studied the parabolic dune adjoining from the south the dune examined at present. These investigations resulted in recognition of the deposits of braided river, which functioned till the Oldest Dryas, its flow direction, and two phases of migrating dune formation (in Older and Younger Dryas). The organogenic infilling of the fossil cut-off channel, dated to the Bølling, permitted to reconstruct environmental conditions of this reservoir. The next research was carried out in the early 1990s. Based on the detailed ex-



Fig. 1. Location of research site against the background of geomorphological sketch according to Nowaczyk (1986), partly changed. amination of fluvial, aeolian and biogenic deposits, the researchers identified the conditions of transformation of braided river into meandering one. Moreover, they distinguished new deposition environments, i.e. reworked and wet aeolian and fluvio-aeolian. They also found the paleosol dated to the Bølling and corresponding to the organogenic infilling of fossil channel (Bohncke et al., 1995). Kozarski and Nowaczyk (1995) summed up the investigations in the Żabinko site and presented palaeoenvironmental reconstructions of the end of Vistulian and the beginning of Holocene, especially of palaeoclimate as well as fluvial, aeolian and cryogenic processes. All above-mentioned authors determined the stratigraphic position of the examined deposit units basing on radiocarbon dating of organogenic deposits and paleosols.

Though the quoted papers explain the conditions of transformation of braided river into meandering one, the variability of intensity and character of aeolian processes and the stratigraphic position of main units, it seems that the position of the unit I and II (distinguished and dated to the Plenivistulian by Bohncke et al., 1995) is not precisely determined. They are covered by the paleosol from the Bølling period so it is also possible to date them to the Oldest Dryas, i.e. Late Vistulian. The stratigraphic position of fluvio-aeolian deposits also seems to be dubious. For this reason we undertook next investigations, the more so because new deposit series were exposed in the site. Therefore, the study was conducted to determine the vertical extent and TL age of individual lithofacial complexes, and to characterize paleosols. The obtained TL ages of the examined deposits were compared with the non-calibrated results of radiocarbon dating.

\section{METHODS}

The defined goals were accomplished based on field work in the exploitation exposure of sand pit. Three profiles were exposed in the examined dune complex: longitudinal section of its proximal part, longitudinal section and cross-section of its distal part. Field work included: a) lithological description of deposits - identification of texture and sedimentation structures; b) measurements of scale and frequency of the identified lithofacies and structural directional elements; c) recording of periglacial structures; d) pedological description of paleosols; e) sampling for TL dating (Fig. 3H). Based on the evidence collected in the field, we identified deposition environments using lithofacial analysis. The samples of examined deposits were dated using TL method. At first sample moisture was measured. The dose rate (Dr) was determined for a dried sample with use of the "MAZAR95 " gamma spectrometer. The concentrations of ${ }^{226} \mathrm{Ra}$, ${ }^{232} \mathrm{Th},{ }^{40} \mathrm{~K}$ in dry mass were measured. Each sample was measured 20 times, each measurement lasted 2000s. The concentrations of radionuclides were converted into dose rates for alpha, beta and gamma radiation. The dose rate was calculated with the corrections for deposit moisture, 
dose of cosmic radiation, grain size, and time of etching with HF (Aitken and Xie, 1983, Adamiec and Aitken, 1998). Uncertainty of dose rate determination was about 3\% (Poręba and Fedorowicz, 2005). The measurement of equivalent dose $(\mathrm{ED})$ was preceded by preliminary treatment. The 80-100 $\mu \mathrm{m}$ grain fraction, separated by sieving, was treated with $10 \% \mathrm{HCl}$ for twenty-four hours, and then with $2 \% \mathrm{NaOH}$ for the same time. Then grains were etched with $40 \%$ HF for 45 minutes (Bluszcz, 2000). After each treatment a sample was washed with distilled water. The equivalent dose (ED) was measured by the TL multiple-aliquot regeneration technique (Wintle and Prószyńska, 1983). The RA'94 reader-analyser with the BG-39 filter was used. A sample was heated in argon atmosphere to $400^{\circ} \mathrm{C}$ with heating rate of $8^{\circ} \mathrm{C} / \mathrm{s}$. Analysed peak occurred at about $350^{\circ} \mathrm{C}$. Plateau test indicated that plateau occurs between $320^{\circ} \mathrm{C}$ and $380^{\circ} \mathrm{C}$.
Grain sensitivity was tested by additional measurements according to technique used in additive method (Fedorowicz, 2006).

\section{RESULTS}

The structure of the described dunes and their substratum was examined in the $400-500 \mathrm{~m}$ long exploitation exposure cutting the southern parts of front zones and southern arms of the dunes. The following three deposit complexes were distinguished (Fig. 2):

1) Lower, fluvial complex in its bottom part is composed of middle- and coarse-grained sands with trough cross-stratification of medium and small scale and fine sands with ripple cross-lamination. The upper part is rhythmite of sand with ripple crosslamination and sandy silts with ripple, wavy and ho-

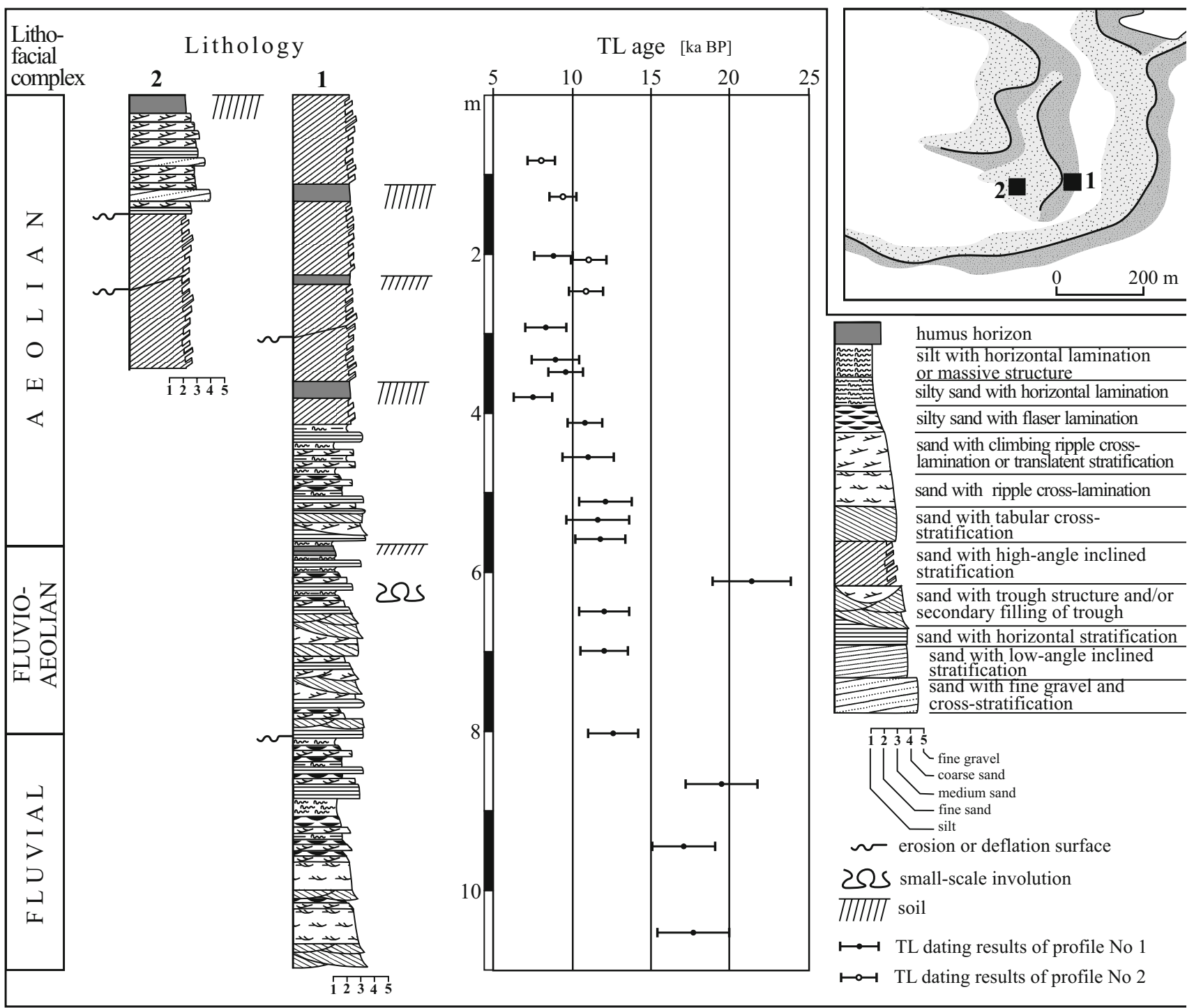

Fig. 2. Results of investigations of fluvial and aeolian deposits in the Żabinko site 


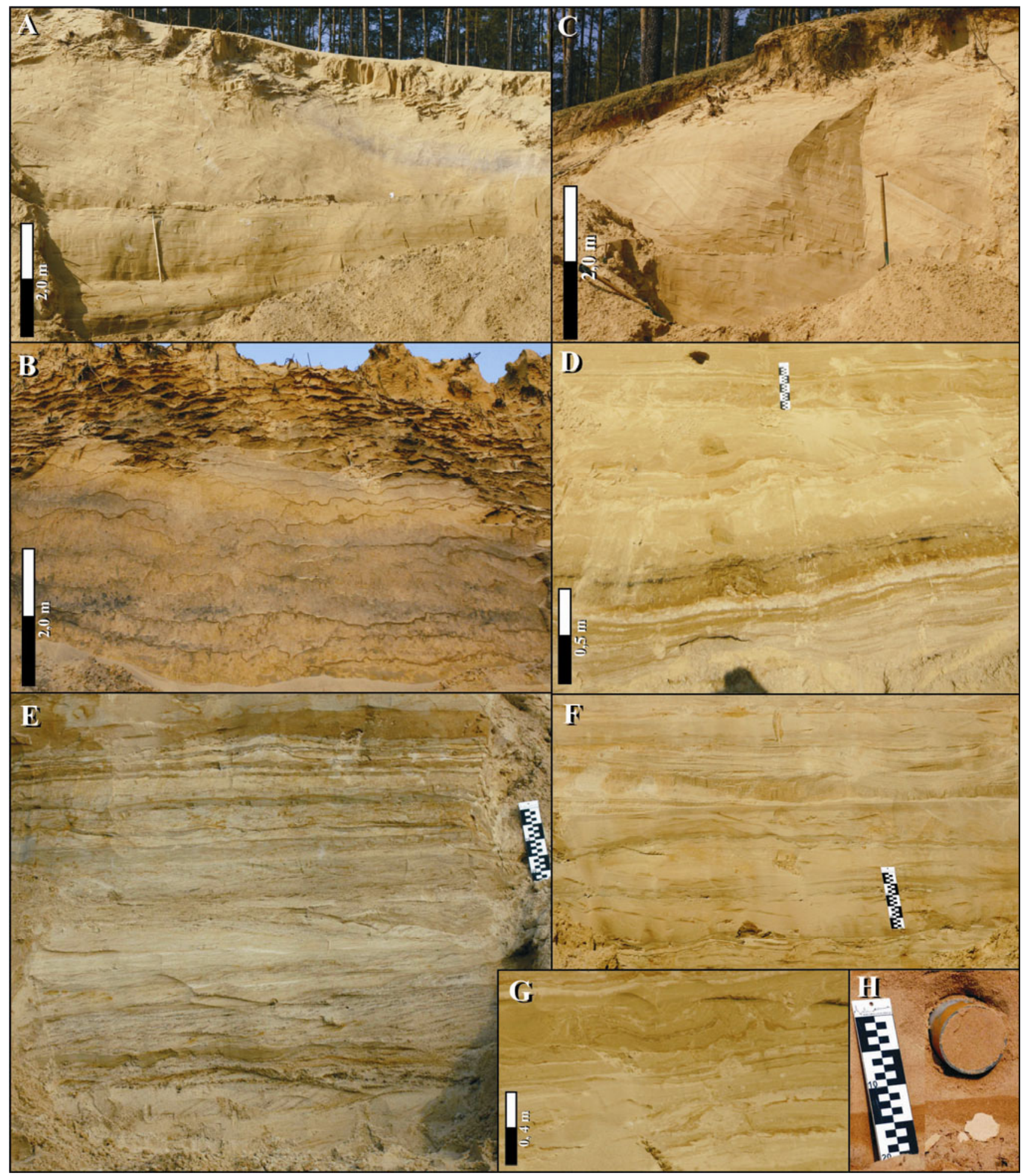

Fig. 3. Lithological features of depositional succession: Iongitudinal section (A) and cross-section (B) of aeolian complex with buried colluvial soils; aeolian complex in proximal part of the site with record of leeslope deposition in bottom and windward slope deposition in top (C); top part of fluvioaeolian complex with initial gley soil and bottom part of aeolian complex with record of deposition on horizontal surface (D); fluvial complex with record of vanishing channel flows of sand-bed braided river and deposition in proximal zone of floodplain (E); fluvio-aeolian complex with record of deposition on wet surface and subcritical flow (F) and with small-scale involutions (G); the way of sampling for TL dating $(H)$. 
rizontal lamination or massive structure (Fig. 3E). Three samples of the deposits were TL dated and the results ranged from $17.1 \pm 2.0$ to $19.5 \pm 2.3 \mathrm{ka}$ (Table 1, Fig. 2).

2) Middle, fluvio-aeolian complex is mostly composed of sands and silty sands with ripple, flaser and massive structure, and medium-grained sands with tabular cross-stratification of medium scale and horizontal stratification. Sands with trough crossstratification of small and medium scale occur in places (Fig. 3F). In the top of the complex there occur from two to four thin, discontinuous humus streaks overlying strongly gleyed silty-sandy deposits (Fig. 3D). Small cryogenic structures in the form of cryoturbations to $8-10 \mathrm{~cm}$ deep are found in the complex (Fig. 3G). Four samples of the deposits were TL dated. Three results ranged from $12.6 \pm 1.6$ to $12.0 \pm 1.6 \mathrm{ka}$ and fourth was $21.4 \pm 2.5 \mathrm{ka}$ (Table 1, Fig. 2).

3) Upper, aeolian complex is composed of two lithofacies associations. The lower association consists of horizontal lithofacies of sands with translatent stratification, climbing ripple cross-lamination or horizontal stratification. In places they are intercalated with silts or silty sands with horizontal or wavy lamination (Fig 3D). Sands with trough stratification of small scale with secondary filling are rare. The upper association is distinctly predominant in the complex and consists mostly of sands with high-angle inclined stratification and with many reactivation surfaces (Fig. 3A). Only in the proximal part, in the top of the complex there were found sands with translatent stratification, climbing ripple cross-lamination or horizontal stratification, and rarely - medium- and coarse-grained sands with low-angle crossstratification (Fig. 3C). These sands are separated from the underlying deposits by vast deflation surface. In the distal part the high-angle lithofacies are separated by several thick (up to $30-35 \mathrm{~cm}$ ) humus horizons of paleosols of colluvial character (Fig. 3A, B). Fourteen samples were TL dated. The results obtained for the lower lithofacies association ranged from $12.1 \pm 1.7$ to $11.8 \pm 1.6 \mathrm{ka}$, and for the upper one - from $11.1 \pm 1.2$ to $7.5 \pm 1.2 \mathrm{ka}$ (Table 1, Fig. 2).

\section{INTERPRETATION}

The fining-up sequences of sand lithofacies with cross structures, which occur in the lower complex, were deposited in the subenvironment of vanishing, shallow channel flows. The silty-sandy rhythmite was accumulated in proximal zone of floodplain (Miall, 1996; Morozova and Smith, 2003; Zieliński, 2007). The recognized fluvial deposition environments are not diagnostic for identification of channel type. However, based on previous investigations (among others Kozarski et al., 1988, Bohncke et al., 1995, Kozarski and Nowaczyk, 1995), we
Table 1. $T L$ dating results of fluvial and aeolian deposits in the Żabinko site

\begin{tabular}{lccccc}
\hline Sample & $\begin{array}{c}\text { Depth } \\
(\mathbf{m})\end{array}$ & $\begin{array}{c}\text { Lab. No } \\
\text { UG }\end{array}$ & $\begin{array}{c}\text { Dr } \\
(\mathbf{G y} / \mathbf{k a})\end{array}$ & $\begin{array}{c}\text { ED } \\
(\mathbf{G y})\end{array}$ & $\begin{array}{c}\text { TL age } \\
(\mathbf{k a})\end{array}$ \\
\hline ZAB 1 & 2.00 & 6181 & $1.88 \pm 0.06$ & $16.5 \pm 1.8$ & $8.8 \pm 1.2$ \\
ZAB 2 & 2.90 & 6182 & $1.63 \pm 0.06$ & $13.5 \pm 1.6$ & $8.3 \pm 1.3$ \\
ZAB 3 & 3.30 & 6183 & $1.69 \pm 0.06$ & $15.0 \pm 1.7$ & $8.9 \pm 1.5$ \\
ZAB 4 & 3.50 & 6184 & $1.78 \pm 0.06$ & $17.1 \pm 1.9$ & $9.6 \pm 1.1$ \\
ZAB 5 & 3.85 & 6185 & $2.76 \pm 0.11$ & $20.7 \pm 2.5$ & $7.5 \pm 1.2$ \\
ZAB 6 & 4.15 & 6186 & $1.77 \pm 0.07$ & $19.1 \pm 2.0$ & $10.8 \pm 1.1$ \\
ZAB 7 & 4.60 & 6187 & $1.83 \pm 0.06$ & $20.1 \pm 2.3$ & $11.0 \pm 1.6$ \\
ZAB 8 & 5.10 & 6188 & $1.83 \pm 0.06$ & $22.7 \pm 2.5$ & $12.1 \pm 1.7$ \\
ZAB 9 & 5.30 & 6189 & $1.64 \pm 0.05$ & $19.0 \pm 2.1$ & $11.6 \pm 2.0$ \\
ZAB 10 & 5.60 & 6190 & $1.75 \pm 0.06$ & $20.6 \pm 2.3$ & $11.8 \pm 1.6$ \\
ZAB 11 & 6.10 & 6191 & $1.84 \pm 0.06$ & $39.3 \pm 4.7$ & $21.4 \pm 2.5$ \\
ZAB 12 & 6.50 & 6192 & $1.93 \pm 0.07$ & $23.2 \pm 2.5$ & $12.0 \pm 1.6$ \\
ZAB 13 & 7.00 & 6193 & $1.85 \pm 0.06$ & $22.2 \pm 2.5$ & $12.0 \pm 1.5$ \\
ZAB 14 & 8.00 & 6194 & $1.97 \pm 0.07$ & $24.8 \pm 2.7$ & $12.6 \pm 1.6$ \\
ZAB 15 & 8.70 & 6195 & $1.99 \pm 0.06$ & $38.8 \pm 4.2$ & $19.5 \pm 2.3$ \\
ZAB 16 & 9.40 & 6196 & $2.11 \pm 0.08$ & $36.1 \pm 4.1$ & $17.1 \pm 2.0$ \\
ZAB 17 & 10.50 & 6197 & $2.17 \pm 0.08$ & $38.4 \pm 4.4$ & $17.7 \pm 2.3$ \\
\hline ZAB 18 & 1.3 & 6149 & $1.68 \pm 0.06$ & $16.1 \pm 1.7$ & $9.6 \pm 0.9$ \\
ZAB 19 & 2.0 & 6150 & $1.73 \pm 0.06$ & $19.2 \pm 2.0$ & $11.1 \pm 1.2$ \\
ZAB 20 & 2.5 & 6151 & $1.81 \pm 0.07$ & $19.7 \pm 2.0$ & $10.9 \pm 1.1$ \\
ZAB 21 & 0.8 & 6152 & $1.64 \pm 0.06$ & $13.3 \pm 1.4$ & $8.1 \pm 0.9$ \\
\hline
\end{tabular}

can relate these deposits to vanishing, secondary channel zone and floodplain of sand-bed braided river.

Lithological features of the middle complex indicate varied accumulation conditions. Sands and silty sands with ripple, flaser and massive structure were deposited by wind on wet surface (Schwan, 1986; Bohncke et al., 1995; Kasse, 2002). In places this deposit was redeposited by low-energy subcritical flows (cf. Bohncke et al., 1995). Such flows are also evidenced by trough lithofacies of small and medium scale. Sands with tabular stratification probably indicate deposition resulting from migration of wind megaripples (Goździk, 1998; Zieliński and Issmer, 2008). Humus streaks occurring on gleyed sandy silts in the top part of the complex indicate the development of initial gley soil on wet substratum during weak but continuous deposition of sediments (Manikowska, 1985).

In the bottom part of the upper complex the horizontally lying sands intercalated with silts evidence various aerodynamic conditions, which resulted in the formation of aeolian cover. High-angle inclined stratification of sands forming the upper lithofacies association of the complex indicates the deposition on the distal slope of dune (Mc Kee, 1966; Hunter, 1977, Lea, 1990). Such type of deposition was also found within the proximal part of the complex dune. This fact indicates that several migrating forms successively developed and encroached on the older ones (Rotnicki, 1970; Nowaczyk, 1976; Zieliński, 2004). This is evidenced by many reactivation surfaces, the vast deflation surface in the proximal part of the dune, and the present morphology of aeolian sands, i.e. complex dune consisting of forms superimposed on 
the windward slopes of previously formed dunes. The occurrence of several humus horizons, separating the high-angle lithofacies in the distal part, is the record of interruptions in aeolian accumulation. Their colluvial character indicates that denudation processes were activated several times and destroyed the previously formed soils. Aeolian processes could have been again initiated on steep distal slope in this way.

\section{DETERMINATION OF STRATIGRAPHIC PO- SITION}

Lithofacial analysis and description of paleosols are especially important for the determination of stratigraphic position of the individual complexes. Based on these studies, we find that two bottom complexes (fluvial and fluvio-aeolian) were formed before the warming recorded as gley paleosol developed in the top of the fluvio-aeolian complex. The TL dating results obtained for the lower complex (from $19.5 \pm 2.3$ to $17.1 \pm 2.0 \mathrm{ka}$ ) indicate its Plenivistulian age (Kozarski and Nowaczyk, 1991). The TL ages from $12.6 \pm 1.6$ to $12.0 \pm 1.6 \mathrm{ka}$ confirm that the fluvio-aeolian complex was formed in the Bølling. The very different result $(21.4 \pm 2.5 \mathrm{ka})$ seems to indicate close vicinity of alimentation area. The mineral material was probably not completely zeroed before deposition because of too short transport. However, the deposits are lacking in lithological features, which could confirm such interpretation. The middle complex is covered by paleosol identical with that dated by Bohncke et al. (1995) at $12.33 \pm 0.37 \mathrm{ka} \mathrm{BP}$ so we relate this complex to the Oldest Dryas. Therefore, the obtained TL ages are probably slightly underestimated. The Oldest Dryas age of the fluvio-aeolian complex does not stand in contradiction to the functioning of braided river till the end of this period, which is accepted in literature (Antczak, 1986; Kozarski et al., 1988, Bohncke et al., 1995, Kozarski and Nowaczyk, 1995). The difference is that the results of our investigations confirmed the intensified aeolian activity on floodplain and episodic river flows, which considerably transformed aeolian deposits. It seems that similar deposits, accumulated mostly on floodplain by high flows and aeolian processes and then transformed by water, were described by Bohncke et al. (1995) as unit II. These processes became considerably weaker in the Bölling period, thus peat sedentation in inactive channels and gley soil development on wet floodplain could have occurred.

The deposits of the upper (aeolian) complex, directly overlying the gley paleosol, were dated in the distal part at $11.8 \pm 1.6-10.8 \pm 1.1 \mathrm{ka}$ and in the proximal part at $11.1 \pm 1.2-10.9 \pm 1.1 \mathrm{ka}$. These TL ages locate the main processes of aeolian deposition between the close of the Older Dryas and the beginning of the Younger Dryas. It seems that some of these TL dates are slightly underestimated. In the opinion of Nowaczyk (1986) and Nowaczyk and Kozarski (1995) the main phase of aeolian deposition in the Żabinko site occurred in the Older Dryas because the aeolian deposits overlie the soil and organogenic deposits from the Bølling and in the distal part are covered by the Allerød soil (radiocarbon dated at $11.14 \pm 0.13 \mathrm{ka} \mathrm{BP}$ ). Therefore, we can state that the upper complex was deposited in the Older Dryas, at first as aeolian cover. Then migrating dunes were formed, with large supply of material from alimentation areas.

The stoppage of aeolian processes in the Alleröd resulted in the development of soils. Kozarski and Nowaczyk (1995) found in the Żabinko site the initial soil and pedolith from this period. The name pedolith, proposed by Manikowska (1985), means the soil-sedimentation zones of the Alleröd age, which occur in lower topographic locations. In the examined new exposure we found only the fragments of colluvial soil in the form of thick humus horizon, with weak podzolization traces, which occurs on the distal slope of the dune. This fact indicates that later aeolian deposition was preceded by activation, at least local, of slope processes and intensive deflation of proximal slopes as is evidenced by the occurrence of vast deflation surface. The blown material built the next aeolian series covering the Allerød soil. The deflation was followed by deposition, which occurred also on the proximal slope. The described series was TL dated in the distal part at $9.6 \pm 1.1-8.3 \pm 1.3 \mathrm{ka}$ and in the proximal part at $9.6 \pm 0.9-8.1 \pm 0.9 \mathrm{ka}$. Therefore, the dune-forming processes in the Żabinko site lasted, as commonly accepted, to the beginning of the Holocene. This fact was also confirmed by Nowaczyk (1986) who examined the adjacent dune.

We found in general two reactivations of deposition processes on the distal slope during the Holocene. The first one was TL dated at $8.8 \pm 1.2 \mathrm{ka}$, i.e. occurred in the Boreal. The deposits from this period are covered by the uppermost paleosol, which probably corresponds to the soil dated by Nowaczyk (1986) at $1.01 \pm 0.11 \mathrm{ka}$ BP. Therefore, it appears that the last reactivation of aeolian processes in the Żabinko site occurred in the Subatlantic period.

\section{CONCLUSIONS}

The gathered data permit us to draw the following conclusions:

1) The deposits and structures described in the site were formed by different deposition processes - fluvial, fluvio-aeolian and aeolian. Pedogenesis developed in the periods of weaker deposition.

2) The described processes were most active in different periods at the turn of the Vistulian and Holocene. Fluvial processes predominated in the Plenivistulian, the Oldest Dryas was characterized by overlapping fluvial and aeolian processes, while the highest aeolian activity occurred in the Older and Younger Dryas. Pedogenesis developed in the warm periods of the Late Vistulian, i.e. Bølling and Allerød. 
3) The TL dating results, obtained for the deposit succession in the Żabinko site, well correspond to the results of previous dating of organogenic deposits. It seems that the TL ages of the Late Vistulian deposits are slightly underestimated but we should take into account that the obtained dates have the uncertainty of more than ten per cent. It means that the TL age of an individual sample can be expressed as the time bracket of even 3000 years.

\section{REFERENCES}

Adamiec G and Aitken MJ, 1998. Dose-rate conversion factors: update. Ancient TL 16(2): 37-50.

Aitken MJ and Xie J 1985. Moisture correction for annual gamma dose. Ancient TL 8: 6-9.

Antczak B, 1986. Transformacja układu koryta i zanik bifurkacji Warty w Pradolinie Warszawsko-Berlińskiej i południowej czesści Przełomu Poznańskiego podczas późnego vistulianu (Channel pattern conversion and cessation of the Warta river bifurcation in the Warsaw-Berlin Pradoline and southern Poznań Gap Secion during the Late Vistulian). Seria Geografia 35 UAM, Poznań: 111pp (in Polish).

Bluszcz A, 2000. Datowanie luminescencyjne osadów czwartorzędowych - teoria, ograniczenia, problemy interpretacyjne (Luminescence dating of Quaternary sediments- theory, limitations, interpretation problems). Geochronometria 17: $104 \mathrm{pp}$ (in Polish).

Bogaart PW, Van Balen RT, Kasse C and Vandenberghe J, 2003. Process-based modelling of fluvial system response to rapid climate change II. Application to the River Maas (The Netherlands) during the Last Glacial-Interglacial Transition. Quaternary Science Reviews 22: 2097-2110, DOI 10.1016/S0277-3791(03)001434.

Bohncke S, Kasse C and Vanderberghe J, 1995. Climate induced environmental changes during the Vistulian Lateglacial at Żabinko, Poland. Questiones Geographicae, Special Issue, 4: 43-64.

Fedorowicz S, 2006. Metodyczne aspekty luminescencyjnego oznaczania wieku osadów neoplejstoceńskich Europy Środkowej (Methodological aspects of luminescence dating of Central Europe's Neopleistocene deposits. Gdańsk, Wydawnictwo Uniwersytetu Gdańskiego: 156 pp (in Polish)

Fryberger SG, Hesp P and Hatings K, 1992. Aeolian granule ripple deposits, Namibia. Sedimentology 39(2): 319-331, DOI 10.1111/j.1365-3091.1992.tb01041.x.

Goździk J, 1998. Struktury sedymentacyjne w eolicznych piaskach pokrywowych w Polsce (Sedimentary structures in aeolian cover sands in Poland). In: Mycielska-Dowgiałło E, ed., Struktury sedymentacyjne $i$ postsedymentacyjne $w$ osadach czwartorzędowych $i$ ich wartość interpretacyjna (Sedimentological and postsedimentological structures in Quaternary sediments and their value for interpretation). Warszawa, UW: 167-191 (in Polish).

Hunter RE, 1977. Basic types of stratification in small eolian dunes. Sedimentology 24(3): $\quad 361-387, \quad$ DOI $\quad 10.1111 / \mathrm{j} .1365-$ 3091.1977.tb00128.x.

Kaiser K, Barthelmes A, Czakó Pap S, Hilgers A, Janke W, Kühn P and Theuerkauf M, 2006. A Lateglacial palaeosol cover in the Altdarss area, southern Baltic Sea coast (northeast Germany): investigations on pedology, geochronology and botany. Netherlands Journal of Geosciences - Geologie en Mijnbouw 85(3): 197-220.

Kase C, 1997. Cold-Climate Aeolian Sand-Sheet Formation in NorthWestern Europe (c. 14-12.4 ka); a Response to Permafrost Degradation and Increased Aridity. Permafrost and Preiglacial Processes. 8. 295-311.

Kasse C, 2002. Sandy aeolian deposits and environments and their relation to climate during the Last Glacial Maximum and Lateglacial in northwest and central Europe. Progress in Physical Geography 26(4): 507- 532, DOI 10.1191/0309133302pp350ra.
Kasse C, Vandenberghe J, van Huissteden J, Bohncke SJP and Bos JAA, 2003. Sensitivity of Weichselian fluvial systems to climate change (Nochten mine, eastern Germany). Quaternary Science Reviews 22: 2141-2156, DOI 10.1016/S0277-3791(03)00146-X.

Kasse C, Vandenberghe D, De Corte F and Van Den Haute P, 2007. Late Weichselian fluvio-aeolian sands and coversands of type locality Grubbenvorst (southern Nederlands): sedimentary environments, climate record and age. Journal of Quaternary Science 22(7): 695-708, DOI 10.1002/jqs.1087.

Koster EA, 2005. Recent Advances in Luminescence Dating of Late Pleistocene (Cold-Climate) Aeolian Sand and Loess Deposits in Western Europe. Permafrost and Periglacial Processes 16: 131143. DOI $10.1002 /$ ppp. 512

Kozarski S and Nowaczyk B, 1991. The Late Quaternary Climate and Human Impact on Aeolian Processes in Poland. Zeitschrift für Geomorphologie N.F., Supplmentband 93: 29-37.

Kozarski S. and Nowaczyk B. 1995. The Bólling interstadial at Żabinko and Late Vistulian environmental changes in middle reach of the Warsaw-Berlin Pradolina. Quaternary Studies in Poland 13: 4353.

Kozarski S, Gonera P and Antczak B, 1988. Valley floor development and paleohydrological changes: The Late Vistulian and Holocene history of the Warta River (Poland). In: Lang G. (ed.) Lake, Mire and River Environments during the last 15000 years, Rotterdam, Brookfirld: 185-203.

Lea PD, 1990. Pleistocene periglacial aeolian deposits in southwestern Alaska: sedimentary facies and depositional processes. Journal of Sedimentary Petrology 60(4): 582-591, DOI 10.1306/212F91F12B24-11D7-8648000102C1865D

Manikowska B, 1985. O glebach kopalnych, stratygrafii i litologii wydm Polski środkowej (On the fossil soils, stratigraphy and litology of the dunes in central Poland). Acta Geographica Lodziensia: 52pp (in Polish).

Manikowska B, 1995. Aeolian activity differentation in the area of Poland during the period 20-8 ka BP. Biuletyn Peryglacjalny 34: 125-166.

McKee ED, 1966. Structures of dunes at White Sands National Monument, New Mexico (and a comparison with structures of dunes from other selected areas). Sedimentology 7(1): 1-69, DOI 10.1111/j.1365-3091.1966.tb01579.x.

Miall D, 1996. The Geology of Fluvial Deposits. Sedimentary Facies, Basin Analysis, and Petroleum Geology. Springer, Berlin: 582 pp.

Morozova GS and Smith ND, 2003. Organic matter deposition in the Saskatchewan River floodplain (Cumberland Marshes, Canada): effects of progradational avulsions. Sedimentary Geology 157: 1529, DOI 10.1016/S0037-0738(02)00192-6.

Nowaczyk B, 1976. Geneza i rozwój wydm śródlądowych w zachodniej części pradoliny warszawsko-berlińskiej w świetle badań struktury, uziarnienia i stratygrafii budujących je osadów (The genesis and development of inland dunes in the western part of the Warsaw-Berlin Pradolina in the light of examinations of the structure, granulation and stratigraphy of the deposits which built them). Prace Komisji Geograficzno-Geologicznej, PTPN 16: 108pp (in Polish)

Nowaczyk B, 1986. Wiek wydm, ich cechy granulometryczne i strukturalne a schemat cyrkulacji atmosferycznej w Polsce w późnym vistulianie $\mathrm{i}$ holocenie (The age of dunes, their textural and structural properties against atmospheric circulation pattern of Poland during the Late Vistulian and Holocene). Seria Geografia 28. Poznań, Wyd. Naukowe UAM: 245pp (in Polish).

Poręba GJ and Fedorowicz S, 2005. Gamma spectrometry for OSL and TL dating of loess deposits at Dybawka and Tarnowce (SE Poland). Geochronometria 24: 27-32.

Rasmussen SO, Seierstad IK, Andersen KK, Bigler M, Dahl-Jensen D and Johnsen SJ, 2008. Synchronization of the NGRIP, GRIP, and GISP2 ice cores across MIS 2 and palaeoclimatic implications Quaternary Science Reviews 27: 18-28, DOI 10.1016/j.quascirev.2007.01.016.

Rittenour TM, 2008. Luminescence dating of fluvial deposits: applications to geomorphic, palaeoseismic and archaeological research. Boreas 37: 613-635, DOI 10.1016/j.quascirev.2007.01.016. 
Rotnicki K, 1970. Główne problemy wydm śródlądowych w Polsce w świetle badań wydmy w Węglewicach (Main problems of inland dunes in Poland based on investigations of the dune at Weglewice). Prace Komisji Geograficzno-Geologicznej, PTPN 11(2): 146pp (in Polish).

Schwan J, 1986. The origin of horizontal alternating bedding in Weichselian aeolian sands in Northwestern Europe. Sedimentary Geology 49(1-2): 73-108, DOI 10.1016/0037-0738(86)90016-3.

Van Huissteden J, Kasse C, 2001. Detection of rapid climate change in Last Glacial fluvial successions in The Netherlands. Global and Planetary Change 28(1-4): 319-339, DOI 10.1016/S0921$8181(00) 00082-5$

Wintle A and Prószyńska H, 1983. TL dating of loess in Germany and Poland. PACT, 9. 547-554.

Tobolski K, 1988. Paleobotanical study of Bölling at Żabinko in the vicinity of Poznan, Poland. Quaestiones Geographicae 10: 119124.

Zeeberg J, 1998. The European sand belt in eastern Europe - and comparison of Late Glacial dune orientation with GCM simulation results. Boreas 27(2): 127-139, DOI 10.1111/j.15023885.1998.tb00873.x.

Zieliński P, 2004. Modele rozwoju wydm w zachodniej części Wyżyny Lubelskiej (The models of dune development in the western part of the Lublin Upland). In: Wojtanowicz J, ed., Formy $i$ osady eoliczne. SGP, Poznań: 77-84 (in Polish).

Zieliński P and Issmer K, 2008. Propozycja kodu genetycznego osadów środowiska eolicznego (The proposal of genetic code of aeolian deposits). Przeglad Geologiczny 56(1): 67-72 (in Polish).

Zieliński T, 2007: The Pleistocene climate-controlled fluvial sedimentary record in the Bełchatów mine (central Poland). Sedimentary Geology 193(1-4): 203-209, DOI 10.1016/j.sedgeo.2005.06.016. 